\title{
ANALISIS TEORI JARINGAN AKTOR PADA CO-WORKING SPACE DAN KOMUNITAS STARTUP DI BANDUNG
}

\author{
Fauzan Alfi Agirachman', Agus S. Ekomadyo \\ ${ }^{1}$ Program Studi Magister Arsitektur, SAPPK, Institut Teknologi Bandung \\ ${ }^{2}$ Kelompok Keahlian Perancangan Arsitektur, SAPPK, Institut Teknologi Bandung \\ Jl. B, Lb. Siliwangi, Kecamatan Coblong, Kota Bandung \\ *Email: ${ }^{\text {fauzan.alfi@gmail.com }}$
}

\begin{abstract}
ABSTRAK
Co-working hadir sebagai gaya hidup bekerja mandiri yang mengutamakan nilai kolaborasi, keterbukaan, komunitas, aksesibilitas dan keberlanjutan. Gaya hidup tersebut dimanifestasikan secara arsitektural dalam bentuk tipologi co-working space yang kini menjadi fenomena yang sering dijumpai di kotakota besar di Indonesia. Hal ini terjadi seiring dengan munculnya berbagai komunitas startup atau perusahaan rintisan yang masing-masing dari mereka membutuhkan ruang kerja yang nyaman dan terjangkau. Hadirnya co-working space sebagai sebuah place didukung oleh kehadiran komunitas startup sebagai society di dalamnya. Dengan mengambil kasus co-working space dan komunitas startup di kota Bandung dengan metode relasi antara artifak dan aktor menggunakan Teori Jaringan Aktor (Actor Network Theory/ANT), tulisan ini menelusuri relasi antara kehadiran co-working space dengan komunitas startup di kota Bandung. Dalam studi kasus co-working space HackerspaceBDG yang kemudian secara manajerial bergabung dengan Co\&Co Space dan komunitas FOWAB, relasi yang terjadi antara ketiganya ditelusuri dalam 3 momentum: inisiasi, perpindahan lokasi dan pemindahan pengelolaan co-working. Dari analisis yang dilakukan, didapatkan bahwa keberhasilan co-working space sebagai tempat/place bagi komunitas startup berkolaborasi ditentukan oleh intensitas community event (artifak) dan kesinambungan pelaksanaan event (artifak) ditentukan oleh pengelola co-working space sebagai aktor. Hasil analisis tersebut direfleksikan dalam bentuk penanganan desain arsitektur untuk menghadirkan kolaborasi komunitas startup di co-working space.
\end{abstract}

Kata Kunci: place construction, co-working space, budaya lokal, komunitas startup, Bandung.

\section{PENDAHULUAN}

Perkembangan teknologi informasi saat ini memungkinkan hampir segala aktivitas kerja dapat dilakukan di mana saja, tanpa berbatas lokasi. Dengan terhubung dengan jaringan Internet, seseorang dapat menyelesaikan sebuah pekerjaan dari satu tempat di belahan dunia lainnya tanpa harus bertemu di satu titik atau menyelesaikan pekerjaan secara remote. Hal ini memicu munculnya sebuah gaya hidup bekerja baru yang dikenal sebagai co-working.

Menurut Hibbert et.al. (2010), Coworking merupakan sebuah gaya hidup yang menyatukan konsep bekerja mandiri dan tetap menghadirkan interaksi sosial yang umumnya terjadi di ruang kerja konvensional. Cara bekerja co-working pertama kali diperkenalkan oleh Brad Neuberg pada tahun 2005.

Neuberg (2005) mengungkapkan bahwa co-working menawarkan konsep kantor dengan pekerjaan seperti korporasi pada umumnya, namun dengan cara yang unik. Co-working juga menjadi solusi bagi mereka yang ingin bekerja secara independen tanpa merasa kesepian karena tidak dikelilingi oleh lingkungan para pekerja. Cara bekerja co-working sangat ideal bagi para penulis independen, programmer dan profesi lainnya yang bekerja menggunakan komputer jinjing. Kegiatan bekerja secara co-working dimanifestasikan secara arsitektural dalam bentuk co-working space yang dapat menumbuhkan kolaborasi sesama pekerja di dalamnya.

Di saat yang sama, kemunculan startup sebagai bentuk usaha baru menjadi fenomena di kalangan komunitas digital di Indonesia. Startup atau perusahaan rintisan, merujuk pada perusahaan yang belum lama beroperasi dan masih dalam tahap berkembang dengan jumlah pegawai kurang dari 20 orang. Umumnya, startup yang hadir di Indonesia beroperasi di 
bidang teknologi digital atau dikenal sebagai digital startup dan produk yang dihasilkan berupa aplikasi untuk ponsel pintar atau portal Web yang memiliki fungsi atau layanan tertentu.

Untuk menciptakan ekosistem startup yang berkelanjutan (sustainable), startup di setiap kota membentuk sebuah komunitas startup. Menurut Feld (2012), pembentukan komunitas startup di setiap kota dilandasi oleh beberapa kerangka berpikir, antara lain penggumpalan ekonomi (agglomeration economies) yang membantu startup di area geografis sama dapat berbagi input bersama (common inputs) seperti infrastruktur, jasa legal, penyedia, dan lain-lain yang dapat memberikan benefit ekonomi langsung untuk startup lainnya; efek jaringan (network effects) di mana jejaring yang kuat memudahkan para startup menumbuhkan perusahaan dan menginspirasi startup lainnya; jaringan horizontal (horizontal networks) yang menjalin hubungan berupa budaya berbagi informasi antar sesama startup; dan wilayah yang memiliki masyarakat kreatif.

Dalam keberjalanannya, startup umumnya menggunakan co-working space sebagai lokasi mereka bekerja. Keputusan ini dipilih karena pada tahap awal, startup beroperasi dengan dana minimum dan jumlah pegawai yang sedikit. Selain itu, co-working space digunakan sebagai tempat berkumpul komunitas startup untuk menyelenggarakan berbagai kegiatan seperti seminar, workshop atau kopi darat.

Hadirnya co-working space sebagai sebuah place didukung oleh kehadiran komunitas startup sebagai warga di dalamnya. Dengan mengambil kasus co-working space dan komunitas startup di kota Bandung dengan metode relasi antara artifak dan aktor menggunakan Teori Jaringan Aktor (Actor Network Theory/ANT), penelitian ini menelusuri relasi antara kehadiran co-working space dengan komunitas startup di kota Bandung. ANT menempatkan agensi manusia (aktor) dan agensi non-manusia (artefak) secara simetris (Ekomadyo, et al., 2013). Dengan menggunakan analisis ANT, akan dipahami lebih jauh tentang peran dan aktivitas komunitas startup di Bandung sebagai aktor yang mendukung kehadiran co-working space.

Studi kasus yang digunakan adalah komunitas Forum Web Anak Bandung (FOWAB) sebagai aktor dan co-working space HackerspaceBDG sebagai artifak dengan menggunakan analisis ANT.

\section{METODE PENELITIAN}

Penelitian ini dilakukan secara kualitatif dengan wawancara narasumber dan pengalaman langsung penulis di dalam komunitas sebagai data primer. Narasumber adalah komunitas Forum Web Anak Bandung (FOWAB) diwakili oleh Yohan Totting yang juga salah satu pencetus HackerspaceBDG dan Dimas Satrio sebagai pengurus FOWAB dan HackerspaceBDG saat ini. Wawancara yang dilakukan berfokus pada pengungkapan jaringan aktor yang terlibat dalam pembentukan HackerspaceBDG dan relasinya dengan komunitas FOWAB sebagai warga di dalamnya.

\section{HASIL DAN PEMBAHASAN}

Dalam tulisan ini, hasil analisis menggunakan Actor Network Theory (ANT) akan dibahas melalui tiga momentum:

1. Momentum inisiasi, ketika

HackerspaceBDG (HSBDG) diluncurkan oleh komunitas FOWAB dan beroperasi untuk pertama kali di sebuah ruangan sewa di sebuah bangunan di kawasan Tamansari pada tahun 2010 (Gambar 1).

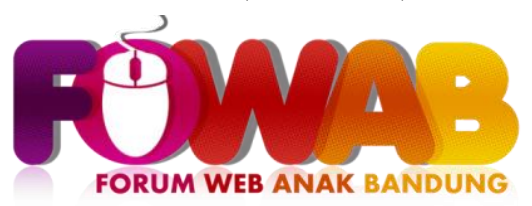

Gambar 1. Logo Komunitas

Forum Web Anak Bandung (FOWAB)

2. Momentum pemindahan lokasi, ketika HSBDG berpindah lokasi ke sebuah rumah tinggal sewa di kawasan Sukaluyu pada tahun 2012.

3. Momentum pemindahan pengelolaan, ketika HSBDG berkolaborasi dengan Co\&Co Space dan berpindah lokasi ke satu bangunan yang sama dengan Co\&Co Space di kawasan Dipatiukur pada tahun 2014 hingga masa beroperasi di akhir tahun 2016.

Berawal dari komunikasi melalui jejaring sosial Twitter, mereka berkumpul untuk membicarakan apa yang dapat dilakukan untuk memajukan Indonesia (Lifepatch, 2012). 
Jejaring aktor yang terbentuk dalam FOWAB ini menjadi cikal bakal terbentuknya co-working space HackerspaceBDG yang menjadi artifak perwujudan hadirnya komunitas.

\section{Momentum Inisiasi: HackerspaceBDG v.1}

Inisiatif pembentukan membuat sebuah co-working space oleh FOWAB berawal dari ide yang dilontarkan oleh salah satu pendiri FOWAB, Yohan Totting mengenai konsep kantor untuk pekerja lepas (freelancer) yang memiliki kebebasan bagi pekerjanya. Sehingga, mereka dapat mengatur konfigurasi ruangnya sendiri sehingga para pekerja lepas dapat meningkatkan produktivitasnya karena lebih fokus dalam menyelesaikan pekerjaannya (Totting, 2009). Selain itu, para anggota komunitas FOWAB memiliki sebuah budaya bekerja work at jelly atau bekerja dengan suasana non-formal di sebuah lokasi yang sudah disepakati oleh anggota komunitas FOWAB lainnya, di Potluck Kitchen, Bandung.

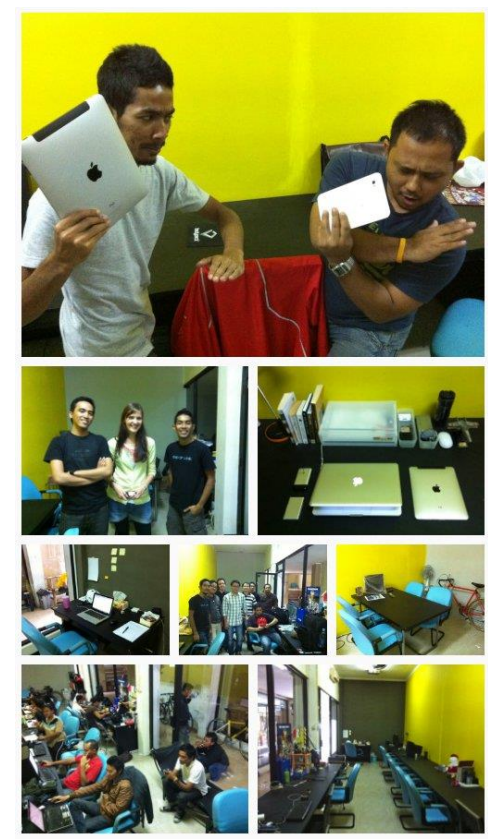

Gambar 2. Suasana HackerspaceBDG v.1 di Tamansari

Sumber: hackerspace.tumblr.com

Niat untuk membentuk co-working space semakin kuat setelah Yohan bersama beberapa anggota FOWAB lainnya berkunjung ke Hackerspace.sg yang berlokasi di Singapura. Berbekal pengetahuan dan pengalaman ketika berkunjung di sana serta pertimbangan biaya work at jelly di Potluck Kitchen yang sulit terjangkau, mereka pun mendirikan co-working space berbasis komunitas pertama di Bandung yang juga pertama di Indonesia dengan nama HackerspaceBDG. Penentuan lokasi HackerspaceBDG pun didasarkan oleh faktor relasi Yohan dengan salah satu anggota, Helmi yang menawarkan ruang kosong yang disewakan di kawasan Tamansari, Bandung. Selain itu, pendanaan awal berupa cicilan untuk penyewaan ruang pun didapatkan dari ibunda salah satu pendiri FOWAB, Reza. Setelah dilakukan renovasi sederhana, HackerspaceBDG resmi berdiri pada 22 November 2016.

Hadirnya HackerspaceBDG menjadi wujud fisik eksistensi komunitas FOWAB di kota Bandung. Momentum ini digunakan oleh FOWAB untuk mengadakan berbagai acara komunitas dan sesi berbagi gagasan (idea sharing) di beberapa lokasi di kota Bandung. Acara komunitas tidak diadakan di HackerspaceBDG dikarena luas bangunannya yang tidak memadai dan hanya mampu diokupansi sebagai co-working space saja. Walaupun begitu, sesi berbagi gagasan sering diadakan di HackerspaceBDG diikuti oleh para startup dan freelancer pengguna co-working space tersebut.

Seiring berjalannya waktu, semakin banyak startup lokal baru yang bergabung dengan FOWAB dan tertarik untuk bekerja di HackerspaceBDG (Gambar 2). Kehadiran HackerspaceBDG dan FOWAB turut dipublikasikan oleh situs portal DailySocial di mana salah satu editor-nya merupakan pengguna HackerspaceBDG.

Selain itu apabila dilihat dari segi tempat (Gambar 4), ruangan yang digunakan cukup padat dan rapat (compact). Ini memungkinkan interaksi antara para pengguna sebagai aktor mudah terjadi yang kemudian memicu kolaborasi antar sesama aktor. Kolaborasi yang terbentuk dapat membuahkan gagasan-gagasan produk baru dari segi bisnis dan berbagai acara komunitas. Secara langsung, hal ini membuat jaringan aktor dan artifak terjalin semakin kuat. Tumbuh kembangnya ekosistem startup di Bandung pun didukung dengan berbagai aktivitas komunitas FOWAB dan para pendiri startup yang memberi pengaruh positif ke seluruh aktor (Gambar 3). 


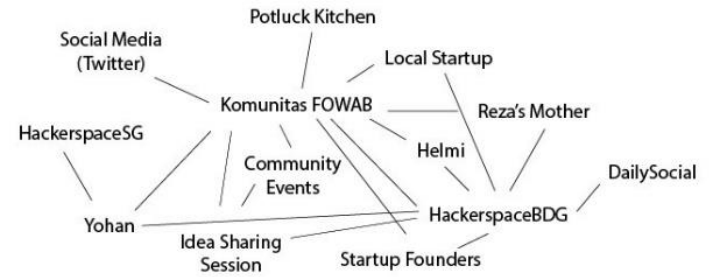

Gambar 3. Sociotechnogram jejaring aktor pada momentum inisiasi HackerspaceBDG v.1

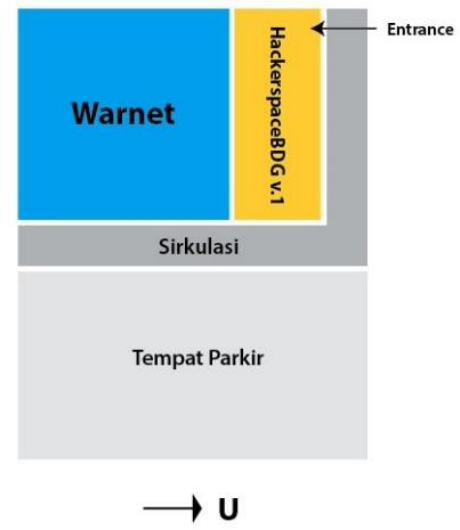

Gambar 4. Layout Ruangan HackerspaceBDG v.1

\section{Momentum Pemindahan Lokasi: HSBDG v.2.0}

Setelah 2 tahun beroperasi di kawasan Tamansari, HackerspaceBDG (HSBDG) pun berpindah lokasi ke kawasan Sukaluyu, Bandung pada awal Februari 2012. Pemindahan lokasi pun didasari oleh faktor eksternal yaitu bangunan yang ditempati akan direnovasi oleh pemilik dan akan diubah menjadi fungsi yang berbeda. Bangunan yang difungsikan sebagai HSBDG v.2 merupakan bangunan rumah tinggal dengan 3 lantai, termasuk lantai atap.

Berbeda dengan sebelumnya, HSBDG v. 2 memiliki luas bangunan yang lebih besar sehingga memungkinkan pengguna dan komunitas FOWAB mengadakan berbagai kegiatan, seperti workshop dan meetup session dengan komunitas-komunitas lainnya (Gambar 5). Adanya ruang penyegaran (refreshing room) di lantai 2 dengan ruang bersama (common room) di lantai dasar dan area garasi yang sering dijadikan sebagai ruang bincang-bincang memungkinkan interaksi dan kolaborasi sesama pengguna, anggota komunitas dan tamu komunitas lainnya pun terjalin (Gambar 6).

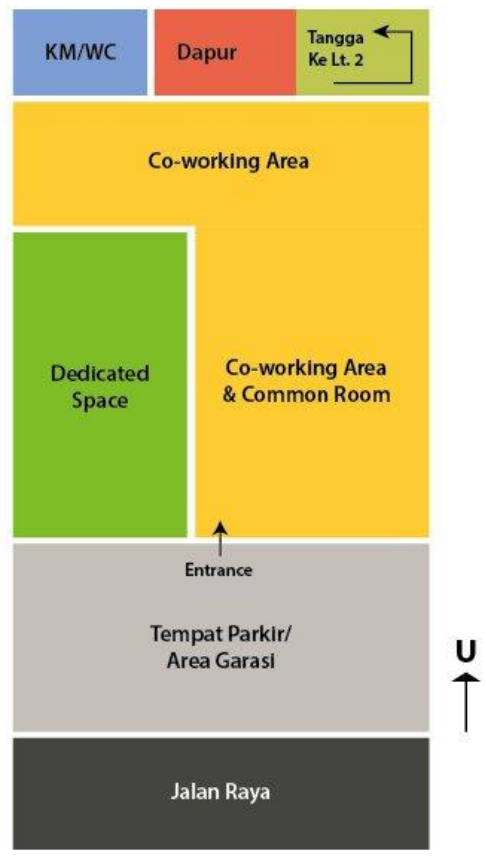

Gambar 5. Layout ruangan lantai dasar HackerspaceBDG v.2

Pada fase ini, ada beberapa jaringan aktor yang terputus dikarenakan faktor relokasi HSBDG ke lokasi yang baru. Walaupun begitu, hal ini tidak memengaruhi jaringan aktor dan artifak telah terjalin. Bahkan karena HSBDG mampu menampung berbagai aktivitas baru yang tidak dapat dilakukan sebelumnya di lokasi lama, jaringan antara aktor dan artifak yang ada semakin kuat dari sebelumnya.

Besarnya pengaruh ketokohan Yohan sebagai pengurus FOWAB dan HSBDG dalam fase ini memberi pengaruh besar dalam mendorong keaktifan Komunitas FOWAB dengan mengadakan banyak kegiatan komunitas (community events) dan sesi berbagi gagasan di dalam maupun di luar HSBDG yang menarik perhatian startup lokal baru untuk bergabung di HSBDG (Gambar 7). 


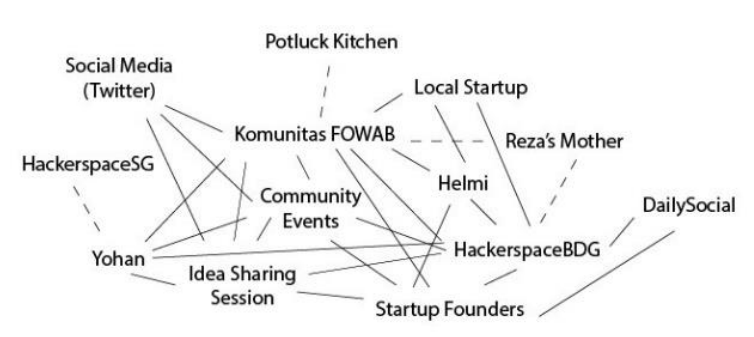

Gambar 6. Sociotechnogram jejaring aktor pada momentum pemindahan lokasi HackerspaceBDG

\section{Momentum Pemindahan Pengelolaan: HSBDG v.3 dengan CO\&CO Space}

Setelah berjalan selama 2 tahun, beberapa kendala muncul di HSBDG v.2 terutama dari sisi pengelolaan bangunan (building management). Yohan sebagai pengelola merasa kewalahan dalam mengelola HSBDG karena di saat yang bersamaan, Yohan tengah sibuk mengelola bisnis yang dia rintis sejak lama. Sehingga, Yohan hanya mampu memenuhi kebutuhan primer pengguna HSBDG saja. Perbaikan bangunan pun sulit dilakukan karena keterbatasan waktu dan pengelolaan yang terpusat pada Yohan saja. Di saat yang sama, Yohan mendapat tawaran dari Ongky mengajak HSBDG untuk "berkantor" di Co\&Co Space di kawasan Dipatiukur pada pertengahan tahun 2014 (Gambar 8). Setelah mendengar tawaran tersebut, maka diputuskan bahwa HSBDG bekerjasama dengan Co\&Co Space dengan menempati salah satu ruang di sana. Co\&Co Space merupakan co-working space komersial di Bandung yang baru diluncurkan saat itu.

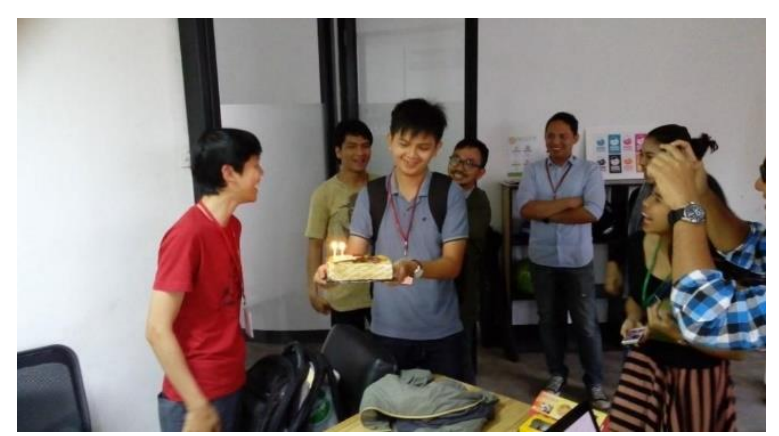

Gambar 7. Suasana HSBDG v.3 di kawasan Dipatiukur, Bandung.

Sumber: twitter.com/hackerspacebdg
Bagi Yohan, kerjasama ini dianggap sangat menguntungkan karena HSBDG dapat fokus kepada pengembangan komunitas dan pengelolaan bangunan diserahkan kepada manajemen Co\&Co Space. Selain itu, HSBDG pun memiliki kewajiban sebagai pengaktivasi tempat (place activator) dan turut mengajak para startup dan freelancer untuk datang dan berkolaborasi di Co\&Co Space. Pengelolaan HSBDG pun dipindahtangankan kepada Dimas Satrio yang juga menjadi pengurus baru komunitas FOWAB. Yohan pun berfokus pada bisnis dan aktivitasnya di berbagai afiliasi. Peran Yohan sebagai pengurus komunitas masih melekat pada dirinya sebagai seorang tokoh dan ketokohan tersebut belum melekat sebagai sebuah institusi. Sehingga, komunitas FOWAB belum dapat berjalan dengan baik tanpa adanya bantuan dari Yohan.

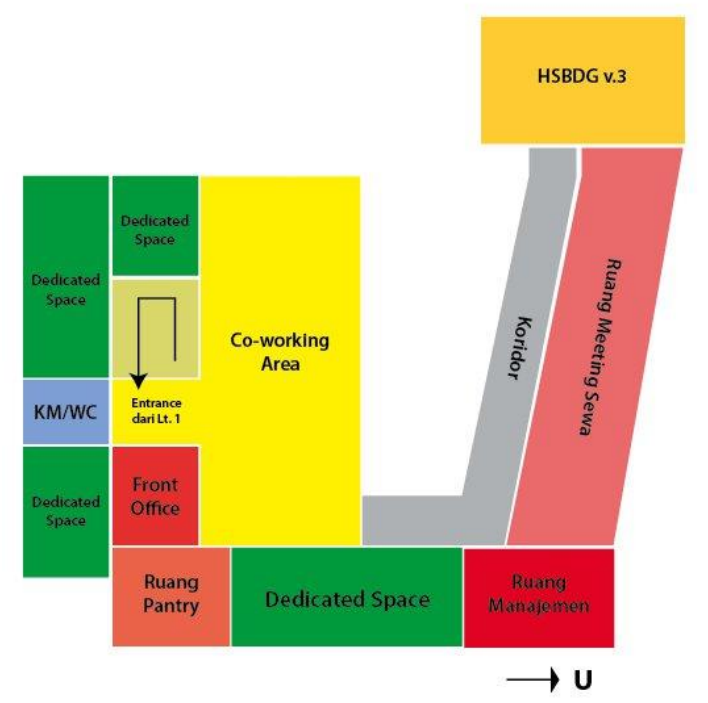

Gambar 8. Layout ruangan HackerspaceBDG v. 3 di dalam area Co\&Co Space

Selain faktor-faktor tersebut, banyak nya jejaring aktor dan artifak yang putus pun disebabkan oleh adanya penggantian manajemen harian Co\&Co Space yang kurang melakukan usaha pendekatan (engagement) dengan startup pengguna Co\&Co dan HSBDG (Gambar 10). Ruang pantry yang umumnya digunakan sebagai simpul bersosialisasi antara pengguna pun hanya berfungsi sebagai pantry saja, tanpa adanya sosialisasi yang terjalin di sana. 


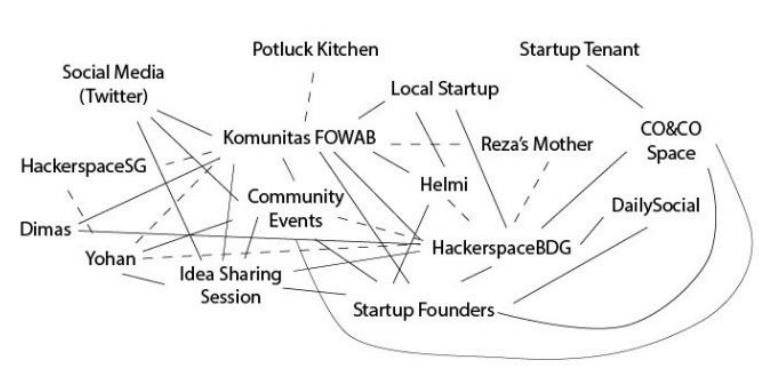

Gambar 9. Sociotechnogram jejaring aktor pada momentum pemindahan pengelolaan HackerspaceBDG ke CO\&CO Space

\section{Perbandingan 3 Momentum}

Sebelumnya, telah dijabarkan tiga momentum yang terjadi selama keberjalanan HSBDG bersama komunitas FOWAB. Dari perspektif ruang, ketiga momentum memiliki tata letak (artifak) dan besaran ruang serta tempat dengan lokasi yang berbeda. Ruangan yang digunakan pada momentum inisiasi HSBDG berukuran kecil dan memanja

ng sehingga para aktor/pelaku yang terlibat berkumpul di ruang yang sama. Hal ini menyebabkan ruang pribadi (personal space) dari masing-masing pelaku yang saling bersinggungan tidak dapat membentuk teritori yang berbeda-beda untuk masing-masing aktor. Melainkan, teritori menjadi lebur dan komunikasi antara pelaku pun menjadi cair terlebih lagi dengan latar belakang yang sama sebagai pelaku startup yang berujung pada pembentukan kolaborasi. Jejaring pun terbangun dengan kuat ketika momentum ini berlangsung.

Pada momentum pemindahan lokasi, ruangan yang digunakan HSBDG memiliki luasan yang lebih besar daripada momentum sebelumnya. Situasi seperti ini memungkinkan adanya teritori yang berbeda-beda dibentuk oleh pelaku di dalamnya. Walaupun begitu, kehadiran ruang bersama dan area garasi sebagai "pusaran" dapat menarik tempat para aktor untuk berkumpul untuk berdiskusi lebih cair dan berujung kepada pembentukan kolaborasi. Sehingga, jejaring yang dibangun sejak momentum inisiasi pun menjadi semakin kuat.

Ketika memasuki momentum pemindahan pengelolaan, HSBDG menempati ruangan yang jauh dari ruang bersama Co\&Co Space yang seharusnya dapat berfungsi sebagai pusaran. Sehingga, HSBDG tidak dapat menjalankan fungsinya sebagai pengaktivasi tempat secara efektif untuk memicu pembentukan kolaborasi. Manajemen Co\&Co Space yang berlokasi sangat dekat dengan ruang bersama seharusnya dapat mengaktivasi tempat. Namun dikarenakan adanya penggantian manajemen, ruang bersama tidak dapat diaktifkan dan hanya berfungsi sebagai ruang kerja sewa biasa tanpa hadirnya semangat berkolaborasi yang menjadi ciri co-working space. Pada momentum ini, jejaring aktor dan artifak menjadi lebih lemah dari sebelumnya. Selain karena situasi yang terjadi di HSBDG dan Co\&Co Space, pelemahan jejaring pun diakibatkan oleh hilangnya pengaruh ketokohan Yohan di dalam komunitas.

\section{KESIMPULAN}

Dari analisis dan perbandingan yang dilakukan, dapat disimpulkan bahwa keberhasilan co-working space sebagai tempat/place bagi komunitas startup berkolaborasi ditentukan oleh intensitas community event (artefak) dan kesinambungan pelaksanaan event (artefak) ditentukan oleh pengelola co-working space dan pengurus komunitas sebagai aktor. Terlebih lagi, apabila ketokohan pengurus komunitas tidak dapat melekat sebagai sebuah institusi namun masih melekat pada individu dari tokoh tersebut, maka keberjalanan komunitas akan terganggu ketika pengurus komunitas pun berganti (adanya pergantian tokoh).

Selain itu apabila dipandang dari kacamata arsitektur, sebuah komunitas dapat menjadi pengaktivasi tempat apabila komunitas tersebut beraktivitas di ruangan yang sama atau berdekatan dengan tempat yang diaktifkan di mana startup-startup lainnya berkumpul. Ketika komunitas startup sebagai pengaktivasi tempat hadir, maka akan terjalin jejaring antara komunitas sebagai aktor dengan aktor-aktor lainnya. Sehingga, interaksi dapat terjalin dengan intensitas yang lebih tinggi.

\section{Daftar Pustaka}

Ekomadyo, A., Prasetyo, F. \& Yuliar, S., (2013) Place Construction and Urban Social Transformation: An Actor Network Theory Analysis For Creative-Kampung Phenomena in Bandung. Prosiding HABITechno International Seminar. 
Bandung: Sekolah Arsitektur

Perencanaan dan Pengembangan

Kebijakan ITB.

Hibbert, C., Kimble, T. \& White, J., (2010) Forecasting Coworking: Architectural strategies for your coworking space. Milwaukee: School of Architecture and Urban Planning University of Wisconsin-Milwaukee.

Lifepatch (2012) FOWAB.

(http://lifepatch.org/FOWAB), diakses pada 9 Desember 2016.

Neuberg, B. (2005) Coworking - Community for Developers Who Work From Home. (http://codinginparadise.org/weblog/20 05/08/coworking-community-for-

developers-who.html), diakses pada 7 Desember 2016.

Totting, Y. (2009) Konsep kantor untuk freelancer.

(https://www.facebook.com/notes/thinkr ooms/konsep-kantor-untuk-

freelancer/178203187065), diakses pada 7 Desember 2016. 